\title{
Diagenesis of Hydrocarbon-bearing Concretions in South-central Puerto-rico: Tectonism and Early hydrocarbon Generation
}

ting ding ( $\nabla$ dingting886@hotmail.com )

East China university of Technology

Luis A. González

The University of Kansas

Fu sheng Guo

East China university of Technology

Yang Xu

East China university of Technology

\section{Research Article}

Keywords: Diagenesis ,Hydrocarbon-bearing Concretions, South-central Puerto-rico

Posted Date: August 23rd, 2021

DOI: https://doi.org/10.21203/rs.3.rs-774307/v1

License: (c) (i) This work is licensed under a Creative Commons Attribution 4.0 International License. Read Full License 


\section{Abstract}

Carbonate concretions within tuffaceous mudstones in the Upper Cretaceous Cariblanco Formation of south-central Puerto Rico that contain solid and liquid hydrocarbons were affected by: 1) Three distinct events of vein/fracture formation accompanied or followed by sediment infilling; 2) pyrite formation throughout the concretion matrix, in foraminiferal chambers, and sediment vein fills; 3 ) four events of larger vein and fracture formation infilled by distinct calcite cements that postdate sediment infilled veins; 4) a late quartz void filling cement; and 5) formation of calcite-filled veinlets that crosscut all components. Petrographic and isotopic data suggest early concretion formation and septarian vein fills, close to the sediment-water interface, prior to any significant dewatering of infilling sediments. The $\delta^{13} \mathrm{C}$ values of the matrix and sediment infills ( -15 to $-30 \%$ PDB), their brightly luminescent character, and the sequestering of $\mathrm{Fe}$ into pyrite indicate formation in a sulfate-reducing environment with influx of diffusing methane. Fluid inclusion data, isotopic composition of carbonate cements (13C enrichments from - 18 to $-8 \%$ and ${ }^{18} \mathrm{O}$ depletion from -4 to $-12 \%$ ), and organic matter maturation suggest maximum burial temperatures of 150 to $200^{\circ} \mathrm{C}$. Calcite cements and microspars were formed by the circulation of progressively warmer fluids, with warming induced by the gradual emplacement of the nearby Los Panes intrusion. The intrusion probably caused intense normal faulting, induced extensive warm fluid circulation, and resulted in a high geothermal gradient responsible for early hydrocarbon generation.

\section{Introduction}

Carbonate concretions and nodules, including the hydrocarbon-bearing concretions reported by Glover (1957), are found in the uppermost Cariblanco Formation of south-central Puerto Rico (Berryhill and others, 1960). The middle Santonian to late Campanian Cariblanco Formation is described by Glover (1961) and additional descriptions are found in Berryhill and others (1960), Berryhill and Glover (1960), Briggs and Gelabert (1962), Pessagno (1960,1962), and Glover (1971). The Cariblanco Formation consists of a sequence of thin to medium bedded siltstones (mudstones) and sandstones intertonguing with medium bedded to massive cobble conglomerates. Four lenticular members of limited distribution are recognized these are the Hacienda Larga Tuff, La Guaba Lava, Jobo Dulce Limestone, and Pio Juan Limestone. In the Coamo area the Cariblanco conformably overlays the Robles Formation, intertongues to the north with the coeval non-marine Achiote Conglomerate and grades upward into the overlying Maravillas Formation.

\section{Geologic Setting}

Puerto Rico ,the easternmost island of the greater Antilles is composed of a Mesozoic and lower Tertiary deformed insland-arc terrain flanked by middle to upper Tertiary carbonate and clastic deposits(Lewis and Draper,1990). Since the end of the Eocene, the regional tectonic of Puerto Rico and the adjacent virgin island has been dominated by left-lateral slip between the North American and Caribbean Plates(Fig. 1). 
The island can be divided into three main morphotectonic zones or provinces( Lewis and Draper,1990), Each separated by two major fault zones that cross the island in a roughly northwest- to south east direction. These are commonly referred to as the Great Southern Puerto Rico Fault Zone(GSPRFZ) and the great Northern Puerto Rico Falut Zone(GNPRFZ)(Glover,1971;Meyerhoff et al.,1983)(Fig. 2). These fault zones divided the island into three areas: the northeast, central and southwest igneous provinces, and have been periodically active since Cenomanian time. The deformation associated with these fault zones is primarily strike slip. However, evidence of shortening is also widespread, as indicated by folded and thrust-faulted rocks.

The Cariblanco Formation in the Coamo area was described by Glover(1961)and additional descriptions are found in Berryhill et al (1960),Berryhill and Glover(1960), Briggs and Gelabert(1962),Pessagono(1960,1962), and Glover(1971). The Cariblanco Formation covers most of the Coamo quadrangle whereas volcanic sandstones, siltstones and mudstones dominate the south and southeast part of the quadrangle. Less abundant lenticlular units of lava and limestone are also present within the Cariblanco Formation and where given member names by Glover(1961,1971), in ascending orders: La Guaba Lava Member, Jobo Dulce Limestone Member, and Pio Juan Limestone Member. The Sabana Hoyos Limestone Member originally included as the top of the Cariblanco Formation by Glover(1961) was redefined by Glover(1971) as the lowermost member of the overlying Maravillas Formation .Ages for the Cariblano Formaiton range from Late Campanian to Middle Santonian based on forminiferal biostratigraphy( Glover,1961,1971; Pessagno,1962). The sources for the Cariblanco Formation were large subaerial dacitic to andesitic volcanoes 15 to $20 \mathrm{~km}$ North of the Coamo area, Conglomerates are of submarine slide origin, and the interbedded mudstones and siltstones were deposited by turbidity currents under euxinic conditions in a submarine graben or silled basin(Glover,1971). Reworked tuff and lapilli tuff constitute about 15 percent of the volcaniclastic part of the Cariblano Formation. The Cariblanco in the Coamo area conformably overlies the Robles Formation, intertongues to the north with the coeval non-marine Achiote Conglomerate,and is conformably overlained by the Maravillas Formation(Glover,1971)(Fig. 3).

\section{Sampling And Methods}

Fieldwork was performed during three field seasons in 1997,1999 and 2016.Fieldwork was concentrated on geologic recognition of previously mapped geologic structures and lithologies of the Coamo quadrangle(Glover,1961;1971),search/assessment and sample collection of concretion sites and lithologies showing calcite veins. A total of 165 hand samples were collected(Fig. 4), which represent the most abundant lithologies within the study area. Special emphasis was given to the collection of concretionary material and any lithologies containing calcite veins.Access to a rather large area southeast of Coamo quadrangle was denied since it belongs to the Puerto Rico National Guard Salinas training area. Even though this area holds the type section for the Cariblanco Formation, the author believes that all the lithologies and structures in the Coamo quadrangle are well represented in the same units studied outside the Salinas training area. 
Concretions were removed intact from the host rocks after taking their orientation. Each concretions was cut in two equal pieces along the longest axis. Half of the slabs were polished for macroscopic observations and the remaining half cut to produce standard $50 \times 76 \mathrm{~mm}$ polished thin sections for standard and cathodoluminescence petrography. After thin-section preparation, chips facing the thin section surface were then polished and used for micro sampling or further slabbed to produce doubly polished thick sections(Fig. 5). Powdered samples of representative diagenetic components ranging from 0.2 to $0.5 \mathrm{mg}$ were extracted using a $500 \mu \mathrm{m}$ tungsten-carbide bit using a microscope mounted dental drill.

Fluid inclusion homogenization temperatures were determined on doubly polished thick sections in a dry nitrogen atmosphere using a Fluid Inc. frzzing/heating stage mounted on a Zeiss microscope. Homogenization temperatures reported here were reproduced at least once and are accurate to at least $0.1^{\circ} \mathrm{C}$.

Carbon and oxygen stable- isotope analyses were determined using an ICP-MS at measured ate the university of Kansas .Samples were extracted using a microsampling device designed for high resolution milling to recover $200 \mu \mathrm{g}$ powders. Samples were roasted at $380^{\circ} \mathrm{C}$ for one hour under vacuum to remove volatiele organic contamination. Samples were subsequently reacted with anhydrous phosphoric acid at $72^{\circ} \mathrm{C}$ in Carbonate reaction system attached to the inlet of a Finigan MAT-257 ratio mass spectrometer. All analyses are reported relative to PDB and precision was maintained to better than $0.1 \%$ o for both $\delta^{18} \mathrm{O}$ and $\delta^{13} \mathrm{C}$.

\section{Result}

\section{1 isotope data}

Matrix calcite has $\delta^{13} \mathrm{C}$ compositions ranging from -30.5 to $-23.6 \%$ and $\delta 180$ values ranging from -1.9 to $-3.1 \%$ o. Internal sediments exhibit overlapping $\delta 13 \mathrm{C}$ compositions ranging from -25.2 to $-17.0 \%$ o. The first generation sediment fill exhibits $\delta 180$ compositions ranging from -1.1 to $-2.8 \%$, and is slightly heavier than the second and third generation of infills which have $\delta^{18} 0$ compositions ranging from -2.3 to $-4.1 \%$ o(Fig. 6).

The first generation of calcite cements (BDC) has compositional ranges of -4.0 to $-5.9 \%$ in $\delta^{18} \mathrm{O}$ and 13.5 to $16.9 \%$ in $\delta 13 \mathrm{C}$. The second generation of cements (FEC) exhibits compositions ranging from 5.8 to $-7.20 \%$ in ${ }^{818} \mathrm{O}$ and -11.8 to $-13.6 \%$ in $\delta^{13} \mathrm{C}$. Interestingly the recrystallized sediments (MSP) exhibit compositions intermediate between these two generations of cements and range from -5.2 to $-6.4 \%$ in $\delta 180$ and -12.7 to $-15.3 \%$ in $\delta 13 \mathrm{C}$. The last two generations of calcite cements (IRC and CSP) have distinct carbon isotopic compositions and overlapping oxygen isotopic composition, with IRC exhibiting slightly heavier $\delta^{18} \mathrm{O}$ values and lighter $\delta^{13} \mathrm{C}$ values. IRC has $\delta^{18} \mathrm{O}$ ranging from -8.8 to $-10.8 \%$ and $\delta^{13} \mathrm{C}$ ranging from -11.0 to $-13.8 \%$ o. CSP has $\delta^{18} \mathrm{O}$ ranging from -9.1 to $-11.8 \%$ and $\delta^{13} \mathrm{C}$ ranging from -7.2 to $-10.7 \%$ o. 


\section{2 fluid inclusion data}

Inclusions are common to abundant in the last two cement phases (IRC and CSP). The inclusions in IRC are single phasesingle-phase inclusion, many fluoresce bright yellow to orange under epifluorescence microscopy suggesting that they are filled by a low API oil (Burrus at al., 1985; Bodnar, 1990).

Two-phase fluid inclusions are present only in the last calcite cement phase (CSP) and the late quartz cement present in few concretions. The inclusions within the late calcite cement can be grouped into three distinct populations based on morphology, abundance and homogenization temperatures. The most abundant inclusions are small "dancing" inclusion generally aligned with cleavage fractures and glide twin boundaries. The homogenization temperatures of these inclusions range from 55 to $75^{\circ} \mathrm{C}$ (Fig. 7). The low temperature and the association with fractures and glide planes suggest leakage during fracturing and twinning. A second group consists of small isolated inclusions with homogenization temperatures ranging form 79 to $94^{\circ} \mathrm{C}$. These inclusions fluoresce blue under UV fluorescence indicating that the inclusion are a heavy API hydrocarbon (REF). The last and the least common of these groups are large isolated inclusions that occur in the distal portions of the CSP cements (late stage cementation closer to pore center). These inclusions preserve the highest homogenization temperatures ranging form 120 to $190^{\circ} \mathrm{C}$. Two-phase inclusions in the late quartz cements are rare and, where present, are isolated and not associated with any crystallographic feature. Homogenization temperatures in these inclusions range from 200 to $240^{\circ} \mathrm{C}$.

\section{Discussion}

The diagenetic history of the Cariblanco concerations is complex but readily interpreted in the context of the known geologic history of the Coamo Region. AS originally suggested by Glover (1971) deposition of Cariblanco sediments took place in an euxinic basin. This is supported by the lack of benthonic fossils and any indirect evidence of benthonic organisms in the matrix; and the abundance of early diagenetic bedding-plane pyrite and pyrite in skeletal chambers of planktonic fossils. The early diagenetic history of these concretions was controlled by the interaction $f$ advecting seawater with organic matter within the sediment and gases diffusing from the underlying sediments. The late diagenetic history as suggested by the oxygen isotopic composition of the vein-filling calcite was largely controlled by thermally driven seawater circulation.

The changes in water and sediment chemistry during organic matter oxidation and the precipitation of diagenetic/authigenic minerals and concretionary carbonates have been the subject of extensive studies (e.g., Claypool and Kaplan, 1974; Irwin and others 1977; Froelich and others, 1979; Gautier and Claypool, 1984; Curtis and Coleman, 1986; and many others). Extensive reviews of early diagenesis in offshore basins is presented by Hesse (1990), of burial diagenesis by Surdam and others (1989), and of isotopic signatures during burial by Longstaffe (1989). 
The presence of pyrite disseminated through the matrix, as distinct layers parallel to bedding, and within skeletal chambers suggests that Cariblanco sediments had progressed into the sulfate reduction zone within the first few centimeters of the sediment water interface. Two lines of evidence indicate that the bulk of pyrite formation took place prior to major concretion forming calcite cementation: a) cross-cutting relationships between pyrite layers and concretion boundaries nucleation of micritic calcite cements around the pyrite crystals/clusters. The horizontal pyrite seams could be the result of enhanced precipitation at a boundary between the iron reduction zone and the sulfate reduction zone where $\mathrm{Fe}^{+2}$ and $\mathrm{HS}^{-}$availability was optimal for sulfide precipitation. Other alternatives that cannot be disregarded are that pyrite precipitation was periodically taking place within the water column itself or that these layers, as well as foraminiferal chambers, were areas of greater sulfate reduction, due to higher organic matter concentration, resulting in localized pyrite formation.

After significant pyrite formation had taken place cementation of the matrix commenced. The $\delta^{18} 0$ of the matrix calcite is within the range of other Santonian marine sediments (cf. Czerniakowski and others, 1983) and indicates that calcite precipitation took place from marine fluids advecting through the sediment column into the sulfate reduction zone. Although depleted $813 \mathrm{C}$ calcite compositions are characteristic of concretions formed within sulfate reducing and/or methane oxidation zones, Cariblanco concretions differ from many other concretions in that they lack any systematic trends in $\delta^{13} \mathrm{C}$ from concretion center to concretion exterior (e.g., Gautier and Claypool, 1984; Ritger and others, 1987). The lack of systematic trends in $\delta^{13} \mathrm{C}$ of concretion matrix and the absence of siderite and abundant pyrite indicates that supply of hydrogen sulfide was plentiful and during matrix cementation progression into the methane generation (fermentation) zone did not occur. The lack of systematic $\delta^{13} \mathrm{C}$ trends in the matrix as well as the limited variability of $\delta^{13} \mathrm{C}$ compositions (7\%) also suggests that the source of organic or organic derived carbon needed to drive sulfate reduction was relatively constant during concretion formation.

Since the matrix $\delta^{13} \mathrm{C}$ composition is several per-mil below that expected for simple organic matter oxidation through sulfate reduction (-22 to -25\%; e.g., Irwin and others, 1977), an additional source of $13 \mathrm{C}$ depleted carbon is required. It is likely that in addition to sulfate reduction bacterially mediated methane or light weight hydrocarbon oxidation was also taking place (Longstaffe, 1989; Hesse, 1990). Two possible sources of methane and other lightweight hydrocarbons are a) fermentation reactions taking place below the sulfate reduction zone or simultaneously within the sulfate reduction zone or $b$ ) thermogenic methane (or light molecular weight hydrocarbons). If significant amounts of methane were being oxidized it is unlikely that fermentation derived methane $(\delta 13 \mathrm{C}<-50 \%$ ) was a major source as that would result in extremely depleted $\delta 13 \mathrm{C}$ compositions. Either the fermentation derived methane contribution was minimal, or thermogenic methane ( $\delta 13 \mathrm{C}$ range of -35 to $-50 \%$; Schoell, 1980 ) was being oxidized. It is difficult to determine which of these alternatives is the most likely; though given the association of concretion with hydrocarbons, early thermogenic methane generated during early catagenesis is a preferred alternative. 
With progressive, though shallow, burial the stress heterogeneity due to cementation of concretions and compacting uncemented sediments led to early fluid overpressuring within the concretions resulting in the earliest vein formation (Astin, 1986) and infilling by sediments. The shift toward heavier carbon isotopic composition of the sediment infills (-17 to $-25 \%$ o) suggests a diminished contribution of oxidized methane and is compatible with organic matter oxidation through sulfate reduction as the primary or only source of HCO3-. Although this shift in $813 \mathrm{C}$ could also be attributed to the influx of isotopically heavy bicarbonate produced during methanogenesis, the absence of iron-rich carbonates or siderite suggests that $\mathrm{Fe}+2$ was still being sequestered into sulfides and that sulfate reduction was the dominant organic matter oxidation reaction. The oxygen isotopic composition of SF1 suggests temperatures and fluid compositions similar to those prevalent during matrix cementation, i.e. Santonian seawater at 15 to $20^{\circ} \mathrm{C}$. This suggests a strong advective transport of seawater that prevented any significant temperature increase and provided abundant sulfate to sustain sulfate reduction.

With continued burial further fractures and veins developed leading to emplacement of SF2 and SF3. The similarity of carbon isotopic composition to those of SF1 sediment infills and the presence of disseminated pyrite suggests that sediments were still within the sulfate reduction zone. The shift in the $\delta 180$ values observed in SF2 and SF3 indicates that a temperature increase ranging from 5 to $10^{\circ} \mathrm{C}$ took place after cementation of SF1. This minor shift in temperature was probably a result of both a slightly deeper burial and a decrease in seawater advection allowing fluids to be warmed. Additionally, a change in geothermal gradient could have been caused by the proximity (within 3 to $4 \mathrm{~km}$ ) of the ascending magma that eventually formed the Los Panes Intrusive.

Astin (1986) suggests fractures in concretions is a result of fluid overpressuring during compaction with the fracture geometry controlled by homogeneity or lack of homogeneity in stress fields. In normal compacting basins (i.e. vertical stresses greater than horizontal stresses) vein formation in homogeneous materials, i.e. ellipsoidal or spherical concretions, should result in septarian vein formation. Under non uniform horizontal stresses, such as those present during regional doming, asymmetrical or irregular (i.e., non septarian) vein formation is expected. The pronounced differences in size and geometry of post SF1 veins and fractures found in nodules and blocks and those in ellipsoidal concretions suggests major differences in the stress fields in which these two types of concretions formed. Veins and fractures in ellipsoidal concretions developed mostly by dilation of the first set of veins while in the irregular nodules and blocks new veins and fractures were formed. These differences indicate that there are differences in the stress fields of the different concretion morphologies. These differences are most likely a result of asymmetries in horizontal stresses induced by the initiation of doming caused the ascending Los Panes Magma.

Although $\delta 180$ depleted calcite cements usually are associated with burial diagenesis $(>1 \mathrm{~km})$ it is unlikely that significant burial of Cariblanco sediment took place during concretion formation. Shallowing of the Cariblanco basin occurred and deposition of the Jobo Dulce Limestone Member took place during the progressive emplacement of the Los Panes Magma and the accompanying doming and faulting of the area. Glover (1971) attributed the fine-grained textures of the diorite in the Los Panes Intrusive to rapid 
ascent and cooling. It is very likely that the sharp temperature gradient produced by the rapid emplacement of this hot magmatic body (within 2-3 km of the sea floor) resulted in the initiation of thermally driven seawater circulation (Forster and Smith, 1990; Lewis, 1990).

The active and progressively more vigorous circulation of seawater could have resulted in further hydraulic and thermal expansion fracturing of veins and followed by the emplacement of calcite cements. The progressive $\delta 180$ depletion of the Vein-filling calcite resulted from progressive warming of circulating seawater as magma emplacement proceeded. If calcite cements were precipitated from warm seawater without modification by rock-water interactions, the earliest calcite cements (BDC) require a temperature increase of 10 to $20^{\circ} \mathrm{C}$. The latest calcite cements require a temperature increase of 30 to $40^{\circ} \mathrm{C}$. The fluid inclusion data on CSP cements suggest that a progressive temperature increase was accompanied by increasing rock-water interaction with the thick sequence of volcaniclastics, pelagic limestones and igneous rocks underlying Cariblanco sediments. These interactions resulted in an $\delta 180$ enrichment of circulating seawater of up to 10\%o (Sheppard, 1986; Lawrence, 1989; Longstaffe, 1989). The likely fluid $\delta 180$ enrichment implies that a much higher temperature would be required to account for the $\delta 180$ of calcite cement. Precipitation of the late cement phases, IRC and CSP, could have taken place at temperatures ranging up to $150^{\circ} \mathrm{C}$.

There are several possibilities that can account for the observed trends toward heavier $\delta 13 \mathrm{C}$ compositions. These are: 1 ) an enhanced contribution of heavy (0 to $2 \%$ ) marine dissolved CO2; 2 ) a reduced contribution from organic matter derived $\mathrm{CO} 2 ; 3$ ) rock-water interactions resulting in a contribution from heavy rock carbonate; 4) a contribution from heavy bicarbonate derived from the carbonate reduction zone (methane formation) in areas through which seawater is flowing into the rock; and 5) contribution of heavy magmatic $\mathrm{CO} 2$ produced by the degassing of the ascending magma body (Taylor, 1986). With the onset of active seawater circulation and the increase in temperature it is likely that oxygenated seawater circulated through the system and more "normal" marine dissolved CO2 was contributed to the system. The iron content of FEC cements requires an increase in fluid Fe/Mn ratios. The marked difference in $8180, \delta 13 \mathrm{C}$, and the reactivity of SF1 with fluids precipitating FEC suggests a major change in fluid chemistry, involving an increase in Fe/Mn ratios, warmer fluids, and a less $13 \mathrm{C}$ depleted bicarbonate. As the Los Panes Magma moved upward and doming and faulting increased, major changes in the size, position and the sense of direction of thermally driven convection cells could have occurred at the site of concretion formation(Forster and Smith, 1990). FEC and MSP preserve a record of changing fluid chemistry or flow regime. At or near the peak of convective circulation IRC and CSP were precipitated. The minor difference in the $\delta^{13} \mathrm{C}$ composition of these cements may be attributed to a small decrease in the contribution of oxidized organic matter or hydrocarbons to the dissolved $\mathrm{CO}_{2}$ or to a slightly higher rock-water ratio for the fluids precipitating CSP.

The last pulses of warm fluids were responsible for the precipitation of the late clear quartz present in a few concretions. With the cooling of the Los Panes Magma, the local highs subsided and seawater circulation decreased. 
The latest diagenetic alteration of Cariblanco concretions occurred when the calcite filled veinlets were formed. The leaching of iron from matrix and cements by the fluids from which the veinlet calcite was precipitated demonstrate that there are major differences between these fluids and those that precipitated cements in the major veins and fractures. As these veinlets cut across all other diagenetic fabrics and seem to be associated with the strained fabrics observed in the Vein-filling calcite cements it is likely that these were formed during the Eocene compressional folding and transcurrent faulting that affected the area (Glover, 1971; Erikson and others 1991).

\section{Hydrocarbon generation and emplacement.}

The limited carbonate data does not allow unequivocal determination of the source of the hydrocarbons in the Cariblanco concretions nor when migration occurred. The presence of hydrocarbon in the voids within larger fractures and its survival until modern exhumation indicates that emplacement occurred prior to void sealing and most likely occurred simultaneously with CSP and/or IRC cement formation. The intense anaerobic organic matter degradation that affected Cariblanco sediments likely depleted most organic matter leaving a minor fraction of more resistant terrestrial organic matter.

The emplacement of the Los Panes Magma was the probable cause of a localized elevated geothermal gradient sufficient to initiate petroleum generation deeper in the sediment column. If indeed the relatively stable $\delta^{13} \mathrm{C}$ signature of the concretion matrix reflects the contribution of thermogenic methane, it is likely that methane and other light hydrocarbons were produced deeper within the basin. The migration and emplacement of these hydrocarbons was likely a result of the enhanced solubility/miscibility at temperatures in excess of $125^{\circ} \mathrm{C}$ (Barker, 1980) and the large scale convective flow resulting from the ascent of the Los Panes magma. Accumulation of hydrocarbons at the site of concretion formation was a result of decreasing pressure and/or temperature. Most of the hydrocarbon diffused through the overlying sediments while minor amounts were preserved within some concretions.

\section{Hydrocarbon potential and the tectonics of south-central Puerto Rico}

The presence of volatile hydrocarbons within Cariblanco concretions indicate that conditions for hydrocarbon generation did exist at depth when Cariblanco and possibly Maravillas sediments were being deposited. Because of the limited available data it is difficult to evaluate whether significant amounts of hydrocarbons were ever generated within the Cretaceous Cariblanco basin and what their fate was during the intense post-Campanian fracturing, plutonism and volcanism that affected all of the Cretaceous rocks in the area. It is doubtful that, if generated, any hydrocarbons have been preserved in onshore Puerto Rico.

If we assume that Cretaceous deformation diminished southward, offshore, then any significant amounts of hydrocarbons that were generated could have been preserved in the distal 
portions of the Cariblanco Basin provided they survived Eocene faulting and folding. Extensive and detailed studies of the Cretaceous sedimentary sequence in south-central Puerto Rico are clearly needed to better define the history of hydrocarbon generation in this poorly understood area of the Caribbean.

\section{Declarations}

\section{Acknowledgments}

Funding for this Study was provided by National Natural Science Foundation of China(Grant NO.41902065, 41772197).

\section{References}

1. Astin, T. R., 1986, Septarian crack formation in carbonate concretions from shales and mudstones: Clay Minerals, v. 21, p. 617-631.

2. Barker, C., 1980, Primary migration: the importance of water-mineral organic matter interactions in the source rock: in Roberts, W. H. and Cordell, R. J., eds., Problems of petroleum migration, American Association of Petroleum Geologist Studies in Geology no. 10, p. 19-31.

3. Barker, C. E., and Pawlewicz, 1986, The correlation of vitrinite reflectance with maximum paleotemperature in humic organic matter: in Buntebarth, G., and Stegena, L., eds., Paleogeothermics, Springer-Verlag, New York, p. 79-63.

4. Berryhill, H. L., and Glover, L., 1960, Geology of the Cayey quadrangle, Puerto Rico: U. S. Geological Survey Miscellaneous Geologic Investigations, Map I-319.

5. Berryhill, H. L., Briggs, R. P., and Glover, L., 1960, Stratigraphy, sedimentation, and structure of late Cretaceous rocks in eastern Puerto Rico - Preliminary report: American Association of Petroleum Geologist Bulletin, v. 44, p. 137-155

6. Bodnar, R. J., 1990, Petroleum migration in the Miocene Monterey Formation, California, USA: constraints from fluid-inclusions studies: Mineralogical Magazine, vol. 54, p. 295-304.

7. Briggs, R. P. and Gelabert, P. A., 1962, Preliminary report of the geology of the Barranquitas quadrangle, Puerto Rico: U. S. Geological Survey Miscellaneous Geologic Investigations, Map 1-336.

8. Burruss, R.C., Cercone, K. R., and Harris, P.M., 1985, Timing of hydrocarbon migration: evidenced from fluid inclusions in calcite cements, tectonics and burial history: Special Publication - Society of Economic Paleontologists and Mineralogists, v. 36, p. 277-289.

9. Claypool, G. E., and Kaplan, I. R., 1974, The origin and distribution of methane in marine sediments: in Kaplan, I. R., ed., Natural Gases in Marine Sediments, Marine Sciences, v. 3, op. 99-140.

10. Curtis, C. D., and Coleman, M. L., 1986, Controls on the precipitation of early diagenetic calcite, dolomite and siderite concretions in complex deposition sequences: in Gautier, D. L., ed., Roles of organic matter in sediment diagenesis, Society of Economic Paleontologists and Mineralogists Special Publication no.38, p. 23-33. 
11. Czerniakowski, L. A., Lohmann, K. C, and Wilson, J. L., 1984, Closed-system marine burial diagenesis: isotopic data form the Austin Chalk and its components: Sedimentology, v. 31, p. 863-877.

12. Erikson, J. P., Pindell, J. L., and Larue, D. K., 1991, Fault zone deformational constraints on Paleogene tectonic evolution in southern Puerto Rico: Geophysical Research Letters, v. 18, p. 569-572.

13. Forster, C., and Smith., L., 1990, Fluid flow in tectonic regimes: in Nesbitt, B. E., ed., Short course on fluids in tectonically active regimes of the continental crust, Mineralogical Association of Canada Short Course Handbook no. 18, p. 1-47.

14. Friedman, I., and O'Neil, J. R., 1977, Compilation of stable isotope fractionation factors of geochemical interest: in Fleishcer, M., ed., Data of geochemistry, 6th ed., U.S. Geological Survey Professional Paper, v. 440-kk, 110 p.

15. Froelich, P. N., Klinkhammer, G. P., Bender, M. L., Luedtke, N. A., Heath G. R., Cullen, D., Dauphin, P., Hammond, D., Hartman, B., and Maynard, V., 1979, Early oxidation of organic matter in pelagic sediments of the eastern equatorial Atlantic: suboxic diagenesis, Geochimica et Cosmochimica Acta, v. 43 , p. $1075-1090$.

16. Gautier, D. L., and Claypool, G. E., 1984, Interpretation of methanic diagenesis in ancient sediments by analogy with processes in modern diagenetic environments: in McDonald, D. A., and Surdam, R. C., eds., Clastic Diagenesis, American Association of Petroleum Memoir 37, p. 111-123.

17. Glover, L., 1957, Occurrence of free oil in limestone concretions in Puerto Rico: American Association of Petroleum Geologist Bulletin, v. 41, p. 565-566.

18. Glover, L., 1961, Preliminary report on the geology of the Coamo quadrangle, Puerto Rico: U. S. Geological Survey Miscellaneous Geologic Investigations, Map I-335.

19. Glover, L., 1971, Geology of the Coamo area, Puerto Rico, and its relation to the volcanic arc-trench association: U.S. Geological Survey Professional Paper 636, 102p.

20. Hayes, J. A., 1985, Puerto Rico: reconnaissance study of the maturation and source rock potential of an oceanic arc involved in a collision: Unpublished M. S. Thesis, Stanford University, 74p.

21. Hayes, J., Larue, D., Joyce, J., and Schellekens, J., 1986, Puerto Rico: reconnaissance study of the maturation and source rock potential of an oceanic arc involved in a collision: Journal of Marine Petroleum Geology, v. 2, p. 126-138.

22. Hesse, R., 1990, Early diagenetic pore water/sediment interaction: modern offshore basins: in Mcllreath, I. A., and Morrow, D. W., eds., Diagenesis, Geoscience Canada Reprint Series 4, p. p. 277316.

23. Irwin, H., Curtis, C., and Coleman, M. 1977, Isotopic evidence for source of diagenetic carbonates formed during burial of organic-rich sediments: Nature, v. 269, p. 209-213.

24. Jolly, W. T., Lidiak, E. G., Schellekens, J. H., and Santos, H., 1998, Volcanism, tectonics, and stratigraphic correlations in Puerto Rico: in Lidiak, E. G., and Larue, D. K., eds., Tectonics and Geochemistry of the northeastern Caribbean: Geological Society of America Special Paper 322, p. 134. 
25. Larue, D. K., Montgomery, H., Anderson, R. N., Robinson, E. T., Saunders, J., Harrison, T. M., Moos, D., Morin, R., Paillet, F., Cho, M., González, L. A., Kiester, D., Button, J., and Torrini, R., 1990, Drilling at Toa Baja, Puerto Rico: preliminary results of drilling into a non-volcanic island arc massif: Scientific Drilling, v. 1 (6), p. 283-295

26. Larue, D. K., 1991, The Toa Baja drilling project, Puerto Rico: Scientific drilling into a non-volcanic island arc massif: Geophysical Research Letters, v. 18, p. 489-492.

27. Larue, D. K., and Torrini Jr., R., 1995, Sedimentary basins and petroleum potential of Puerto Rico: in Miller, R. L., Escalante, G., Renemund, J. A., and Bergin, M. J., eds., Circum-Pacifiic Council for Energy and Mineral Resources Earth Science Series, V. 16, Springer-Verlag, Berlin Heildeber, p. 131-136.

28. Larue, D. K., Pierce, P., and Erikson, J., 1991, Cretaceous intra-arc Summit basin on Puerto Rico: in Gillezeau, K. A., ed., Transactions of the 2nd Geological Conference of the Geological Society of Trinidad and Tobago, p. 184-190.

29. Lawrence, J. R., 1989, The stable isotope geochemistry of deep-sea pore water: in Fritz, P. and Fontes, J. Ch., eds., Handbook of Environmental Isotope Geochemistry, Elsevier, p. 317-356.

30. Lewis, T., 1990, Fluids and heat flow: in Nesbitt, B. E., ed., Short course on fluids in tectonically active regimes of the continental crust, Mineralogical Association of Canada Short Course Handbook no. 18, p. 49-74.

31. Lewis, J.F., and Drapper, G., 1990, Geology and tectonic evolution of the northern Caribbean margin: in Case, J.E., and Dengo, G., eds., The Caribbean Region, Decade of North American Geology, V. H, Geological Society of America, p. 77-140.

32. Longstaffe, F. J., 1989, Stable isotopes as tracers in clastic diagenesis: in Hutcheon, I. E., ed., Short course in burial diagenesis, Mineralogical Association of Canada Short Course Handbook no 15, p. 201-277.

33. Meyerhoff, A. A., Krieg, E. W., Cloos, J. D., and Taner, I., 1983, Petroleum possibilities of Puerto Rico: Oil and Gas Journal, v. 81, no. 51, p. 113-120.

34. Pessagno, E. A., 1960, Stratigraphy and micropaleontology of the Cretaceous and lower Tertiary of Puerto Rico: Micropaleontology, v. 6, p. 87-100.

35. Pessagno, E. A., 1962, The upper Cretaceous stratigraphy and micropaleontology of south- central Puerto Rico: Micropaleontology, v. 8, p. 349-368.

36. Price, L. C., 1983, Geologic time as a parameter in organic metamorphism and vitrinite reflectance as an absolute paleogeothermometer, Journal of Petroleum Geology, v. 6, p. 5-38.

37. Ritger, S., Carson, B., Suess, E., 1987, Methane-derived authigenic carbonates formed by subductioninduced pore-water expulsion along the Oregon/Washington margin: Geological Society of America Bulletin, v. 98, p. 147-156.

38. Schoell, M., 1980, The hydrogen and carbon isotopic composition of methane from natural gases of various origins: Geochimica et Cosmochimica Acta, v. 44., p. 649-661.

39. Sheppard, S. M. G., 1986, Characterization and isotopic variations in natural waters: in Valley, J. W., Taylor, H. P., and O'Neil, J. R., eds., Stable isotopes in high temperature geological processes, 
Mineralogical Society of America Reviews in Mineralogy, v. 16, p. 165-183.

40. Surdam, R. C., Dunn, T. L., Heasler, H. P., and MacGowan, D. B., 1989, Porosity evolution in sandstone/shale systems: in Hutcheon, I. E., ed., Short course in burial diagenesis, Mineralogical Association of Canada Short Course Handbook no 15, p. 61-134.

41. Taylor, B. E., 1986, Magmatic volatiles: isotopic variation of C, H, and S: in Valley, J. W., Taylor, H. P., and O'Neil, J. R., eds., Stable isotopes in high temperature geological processes, Mineralogical Society of America Reviews in Mineralogy, v. 16, p. 165-183.

42. Twenhofel, W. H., and Tyler, S. A., 1941, Methods of Study of Sediments: McGraw-Hill, New York. p. $121-122$

\section{Figures}

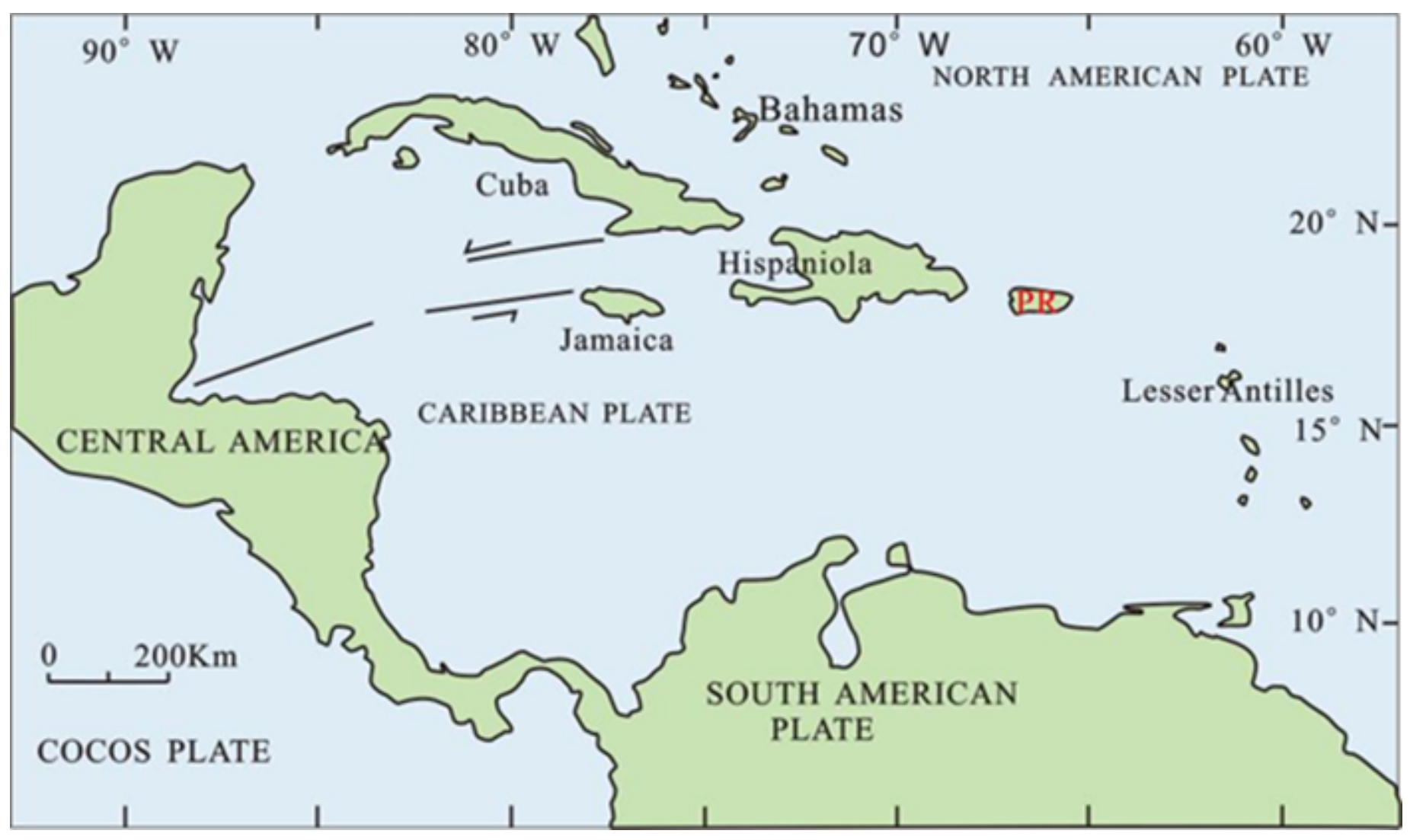

Figure 1

Generalized tectonic features of Caribbean region with Puerto Rico highlighted in red $\$ modify by the Wayne T,2007 [ 


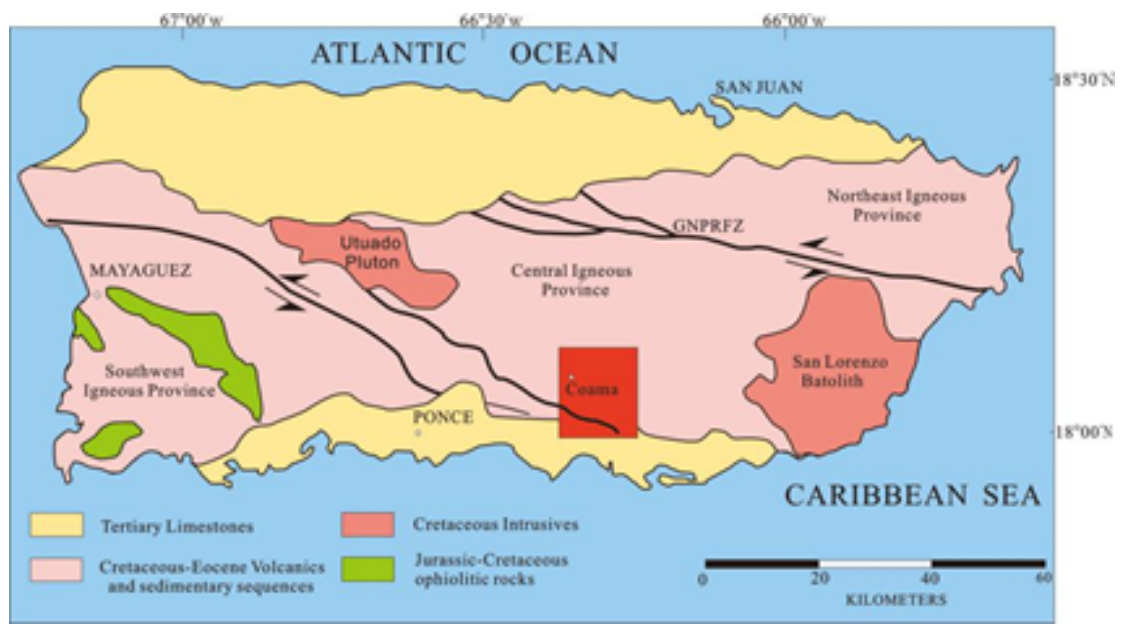

Figure 2

Map of Puerto Rico showing major geologic and tectonic features 

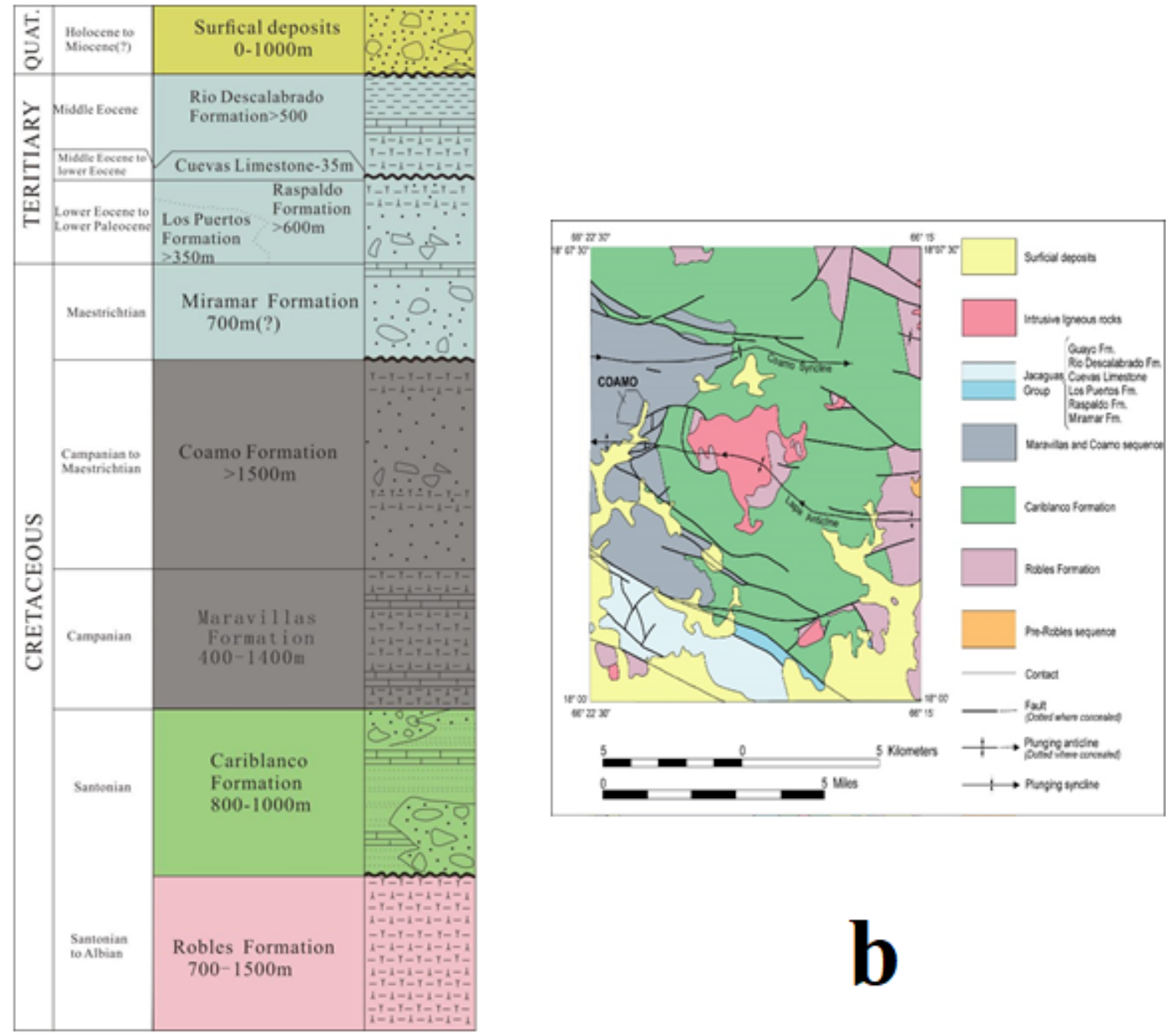

b

a

Figure 3

Generalized stratigraphic column showing main lithologic units in C oamo quadrangle(Modified ftom Glover,1971) 


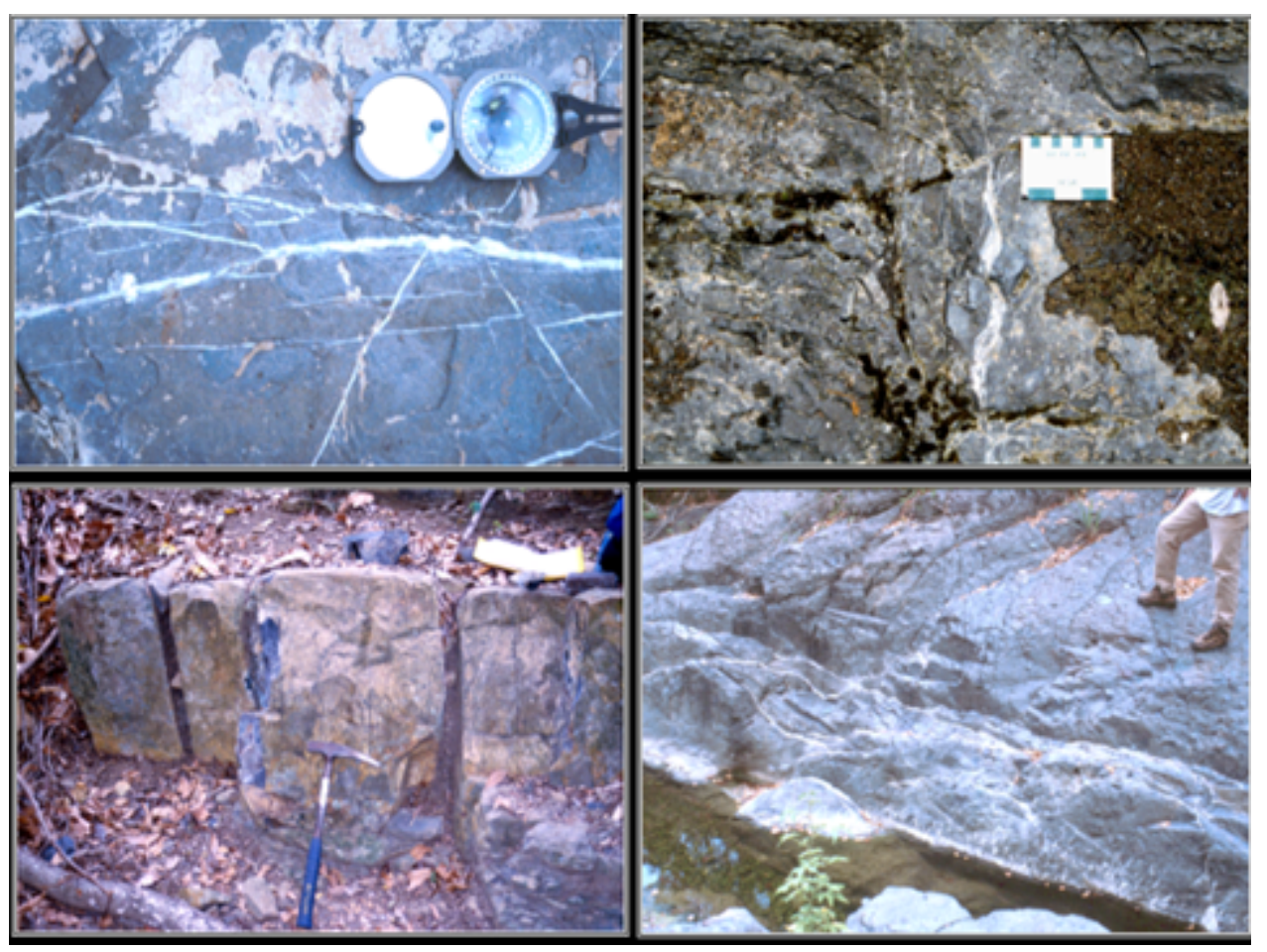

\section{Figure 4}

Explain their field characteristics

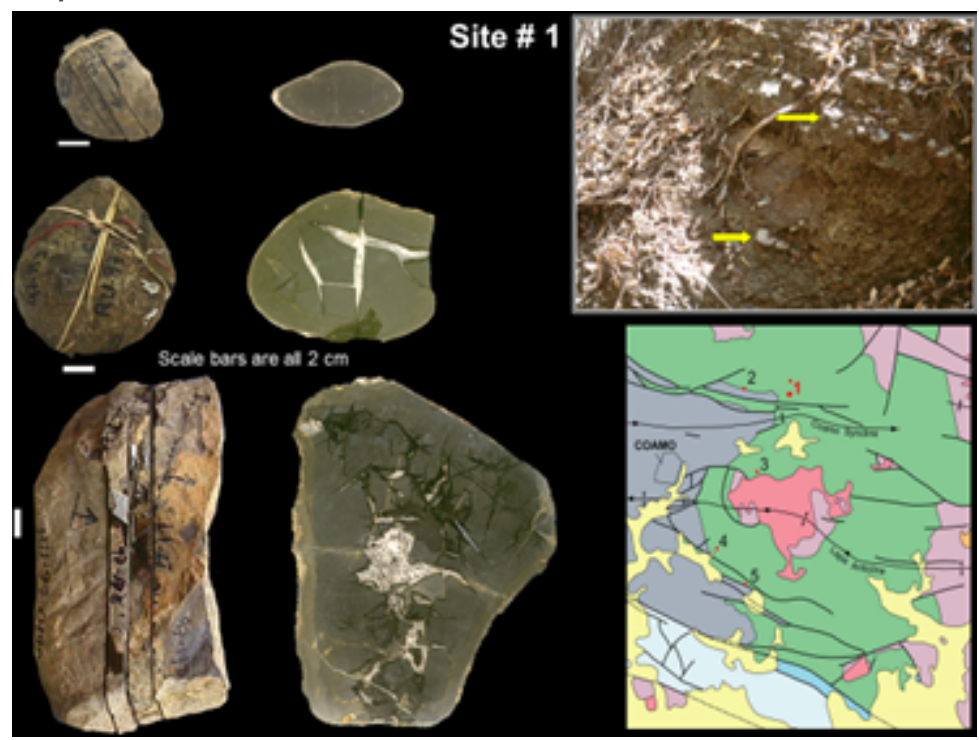

Figure 5

Samples picture 


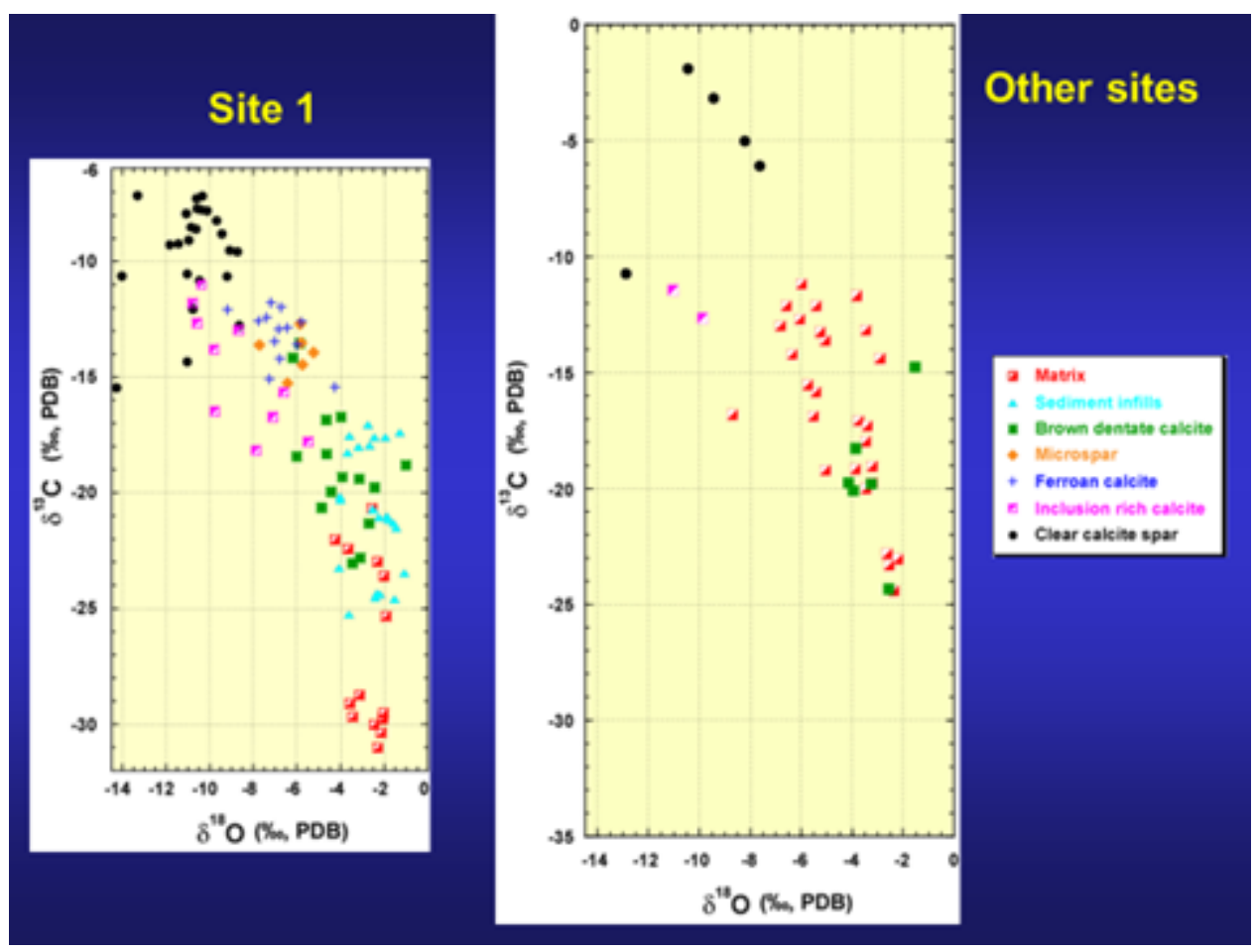

Figure 6

Isotope data

Fluid Oxygen Isotope - Temperature Evolution

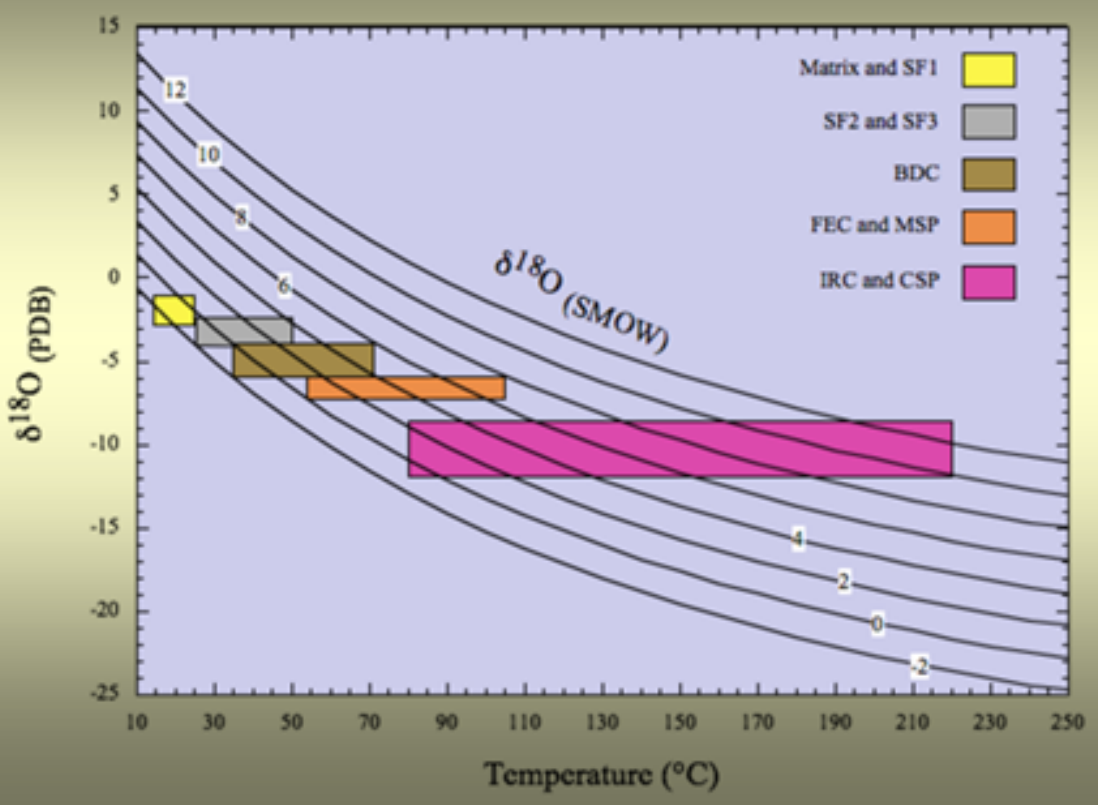

Figure 7

Fluid oxyenisotope -Temperature Evolution 